\title{
European welfare states in competition
}

Citation for published version (APA):

Keizer, P. K. (1997). European welfare states in competition. METEOR, Maastricht University School of Business and Economics. METEOR Research Memorandum No. 010 https://doi.org/10.26481/umamet.1997010

Document status and date:

Published: 01/01/1997

DOI:

10.26481/umamet.1997010

Document Version:

Publisher's PDF, also known as Version of record

\section{Please check the document version of this publication:}

- A submitted manuscript is the version of the article upon submission and before peer-review. There can be important differences between the submitted version and the official published version of record.

People interested in the research are advised to contact the author for the final version of the publication, or visit the DOI to the publisher's website.

- The final author version and the galley proof are versions of the publication after peer review.

- The final published version features the final layout of the paper including the volume, issue and page numbers.

Link to publication

\footnotetext{
General rights rights.

- You may freely distribute the URL identifying the publication in the public portal. please follow below link for the End User Agreement:

www.umlib.nl/taverne-license

Take down policy

If you believe that this document breaches copyright please contact us at:

repository@maastrichtuniversity.nl

providing details and we will investigate your claim.
}

Copyright and moral rights for the publications made accessible in the public portal are retained by the authors and/or other copyright owners and it is a condition of accessing publications that users recognise and abide by the legal requirements associated with these

- Users may download and print one copy of any publication from the public portal for the purpose of private study or research.

- You may not further distribute the material or use it for any profit-making activity or commercial gain

If the publication is distributed under the terms of Article $25 \mathrm{fa}$ of the Dutch Copyright Act, indicated by the "Taverne" license above, 
EUROPEAN WELFARE STATES IN COMPETITION

\section{Int roduction}

The Maastricht Treaty (1992) has meant an important step forwards in the process of European integration. Most attention is paid to the monetary aspect and especially the introduction of a common currency. With respect to the goods market most progress is made in the context of the GATT, in order to lower the common protection wall. Up to Maastricht the labour market was, with some exceptions, not part of deliberate consultations on top level. But now the Treaty has arranged a free European Union (EU) labour market, discrimination between employees of the various member countries is forbidden. The United Kingdom has claimed not to be bound by the social section of the Treaty.

There may be two reasons for this relative silence around the free European labour market issue. First, there are severe differences in opinion between the country members. Tripartite consultations, regularly held in Brussels, between European unions, employers' organizations and 'government' are not very successful. second, it is hoped that the member countries will adapt their institutional frameworks in such a way that central coordination is not necessary anymore.

It is rather easy to understand why it is so difficult to reach agreements in the EU tripartite consultations. The economic and social performances differed much and so with the institutional frameworks. When we compare the unemployment figures, the picture is somewhat more complicated. Since the oil crises in the seventies, also the Northern economies have faced financial troubles leading to lower growth and higher unemployment rates. The global process of economic restructuring requires a level of flexibility that makes it difficult for the Northern economies to maintain their social welfare systems as they had built during the sixties.

Also when looking at the institutions we find major differences between the various EU-members. So is the level of regulation in the Nordic countries much higher than in the Southern countries such as Greece and Portugal. The basic problem of a free labour market in a economically, socially and politically highly heterogeneous $\mathrm{EU}$ is that one-way traffic can take place from south to North. Migration flows will be stimulated from low wage to high wage areas, from high unemployment to low unemployment areas, and from badly organised to well organised social systems. 


\section{Fout! Bladwijzer niet gedefinieerd.}

Suppose there would have been no social services provided by the state. Then basic neoclassical economics would predict a process of factor equalisation, leading to a squeezing out of differences in the levels of wages and unemployment. The introduction of nationally organised redistribution of wealth will mean an incentive for net tax payers to out migrate and for net benefit receivers to immigrate, until the difference between the degree of redistribution has disappeared (Stigler, 1957). If the EU-countries are unable to coordinate their social policies,"spontaneous" institutional adjustment processes will undoubtedly lead to more austerity of the generous systems in the North. May be southern economic growth will stimulate the design of more sophisticated social systems in that region, implying a development in the direction of a higher, more extended, generous and universal level. Although a complete equalisation of institutions will not happen because of the geographic and cultural distance that must be bridged, social conflicts will undoubtedly arise in case of social shopping.

One might hope that spontaneous institutional adjustments will partially solve the internal coordination problems, the question remains however, whether the EU can solve its common external problem in this respect. Demographic developments on the one hand and economic restructuring processes on the other hand, both on a global level, have created a permanently growing problem for the EU-countries in terms of immigration flows. Growing numbers of people try to find a living in the EU-area. Some of them are successful; most of them have a hard living and are simply waiting for better times. Since the seventies the EU-countries have implemented an immigration stop, as a policy reaction on the growth of unemployment. This means that many immigrants, who have entered the EU the last twenty years are illegals, making the situation problematic.

Both questions, that of internal and that of external coordination, are highly intertwined. A well coordinated external policy with respect to immigration, will definitely contribute to a better functioning of the internal labour market. But a well functioning internal market is better able to deal with external pressures.

In this article we will deal with the problem of growing competition between the different institutional frameworks of the national labour markets. In section 2 we will demonstrate that labour market institutions are set up to organize a so-called solidarity transfer. Empirical research with respect to the design of welfare states shows us three patterns to be distinguished, to wit the conservative, the liberal and the social democratic framework (Esping-Andersen, 1990). All three types of institutions have their own view on the content of solidarity. In the Eu after Maastricht 1992, the different structures have to compete with each other. This is the subject of the sections 3, 4 and 5 . In the sixth section we will analyse whether it is possible to maintain a decent 
Fout! Bladwijzer niet gedefinieerd.

level of solidarity, with or without explicit European regulation. In section 7 we will work out a concrete proposal with respect to the minimum internal coordination necessary for a well functioning labour market. In a last section we will deal with the problem of the external immigration pressures and the way Europe could deal with it. We end up with an epilogue.

\section{The Welfare State as a Solidarity Transfer}

When we look at the genesis of the modern European welfare states, they all appear to be reactions on the negative social effects of a free market economy. The nineteenth century was characterised by widespread poverty and unemployment, while the political power was in the hands of conservatives and/or liberals.

Primitive conservatives only saw a problem of order. A society consists of several ranks. Membership of a rank is not a matter of private choice, but in general determined by birth. The lowest rank fulfils the function of being the hands and the feet of society. The task of the first rank is to convince the people of this truth and to maintain law and order. To educate next generations in the true conservative culture the family context is the appropriate environment in which this education must take place. The father represents the authority in the family. In case of violence and criminality suppression is the only efficient answer; in the context of the family as well as the polity. ${ }^{1}$

In later years more sophisticated versions of the conservative view were developed. The problem of order can partially be prevented by organising good care for those people who really need it. When we want to hold society together we must be solidaristic with the people of our rank who are in need of help. On the national level Bismarck was the first who implemented conservative welfare policies. When we look at the organisational pattern we see that the social security arrangements are the core of the system and that the social stratification of society is left intact. This means that solidarity is organised per stratum. For the very poor and unemployed the conservative state will organise work in order to give them a living on subsistence level. For people who are unable to work a social assistance benefit is available, but only if they could not built up social security rights and have no relatives who can care for them. After Bismarck in Germany several other nations have developed conservative welfare states, such as Switzerland and Austria.

The primitive liberal view on the problems of poverty and unemployment in a free market economy was quite different. Liberals were positive about the break down of the ranking society in several European and Anglo-Saxon countries. The United States was

1 Hobbes has analyzed as one of the first social philosophers the problem of authority and control in a so-called modern society (Hobbes, 1651). 


\section{Fout! Bladwijzer niet gedefinieerd.}

considered a shining example. A free market was seen as a progressive mechanism, through which a society would reach high levels of wealth for everyone. So 19th century poverty was interpreted as an unavoidable short term phenomenon. Spontaneous processes of an evolutionary character would give maximum space for individual initiative to improve the situation. This would also imply that for the handicapped people sufficient resources would be available for a decent living. Innate moral sentiments would imply a strong positive income elasticity for "charity". (Locke, 1690; Hume, 1739; Smith, 1759).

When poverty held on during the 19th century, some liberals recognised the necessity of government intervention with respect to the position of the very poor. The optimism about the blessings of the free market for all was recognised to be based on the assumption of rationality of the individual. But in practise not all individuals appeared to meet the basic requirements to be rational and to be able to care for themselves. So must the government protect children against parents who used them as a productive resource for themselves in place of an investment good that must be profitably used by the children themselves when they had become adults (Smith, 1776). The same could be said of the elder people who did not have the energy anymore to care for themselves. So liberals took the political initiative to develop legislation to care for the elderly and to forbid children's labour. Now a liberal welfare state can be interpreted as a set of services, provided by the government, only meant for those who are really unable to earn a living in a free market society: the old, the very poor and the seriously handicapped people. Other people are expected to conclude the necessary assurance contracts on the free market in order to be sure of a decent living in case of bad luck.

A third view that is relevant to understand the genesis of the modern European welfare state is the social democratic view. During the 19th century there is a growing group of people who reject the conservative view being elitist, but also object against the liberal view, being too individualistic. So, in agreeing with the liberals that the capitalist society is an evolutionary improvement compared with the traditional ranking society, they sharply disagree with the liberals in their view that a liberal society is in the interest of the mass of the workers. Where the liberals focus their strategy on the freedom of the individual from governmental coercion, strive the socialists for more than such a kind of freedom (Berlin, 1978). Individuals who do not dispose of any means will not attach much value to a liberal kind of liberty. In other words, the structure of society creates a huge inequality in opportunities between people. It must be the task of the government to regulate society in such a way that all people are socially and politically equal and that all of them have access to a number of basic provisions, such as housing, health care, basic education and an income sufficient to participate in our society. Marx can be 


\section{Fout! Bladwijzer niet gedefinieerd.}

considered as the founding father of this view. Later on the socialist movement split up in two groups. The first continued the revolutionary strategy focussed on the expropriation of the capitalists. The second group adapted the original view into a more evolutionary one (Bernstein, 1899). As soon as the political sector was transformed into a parliamentary democracy, the improvement of the position of the working class had to be strived for by legal means.

The socialist and social democratic movement can, to a large extent, be held responsible for the building up of a universal, extended and generous welfare state. Solidarity in the social democratic sense of the word is not restricted to members of the own rank or to people who are really unable to earn their own living. Solidarity means that every person must have the same opportunities to develop his capacities. The only wealth differences that are socially acceptable are those that are the result of differences in efforts (Tinbergen, 1975). If two people are equal, except their preference for leisure, then wealth (excluding the value of leisure) of the man who spends more hours on working is allowed to be higher, so building up more wealth.

We have shortly sketched three different views on the function of the welfare state. The differences are explained by three different views on an efficient and fair organisation and specification of the concept "solidarity". In practice each country has developed an institutional pattern that can be understood as a mix of the ideal types as just sketched. Political parties are the exponents of particular mixes of principles. In many cases coalitions between two or more parties are necessary for the formation of a cabinet (De Swaan, 1973; Esping-Andersen, 1990). So are the countries in South and Central Europe dominated by conservative and social democratic parties and coalitions. In the Nordic countries the influence of the social democratic view has been overwhelming for already a very long time. During the last three decennia the process of secularisation and individualisation has influenced all European countries. In general we can say that this process has strengthened the influence of the liberal view (Fukuyama, 1992).

In the next section we will deal with the competition between institutional patterns on a free labour market. 
Fout! Bladwijzer niet gedefinieerd.

\section{The Problem of Institutional Competition}

\subsection{Migration}

Migration has been an important phenomenon already since the beginning of human life. As is the case in the animal world, human beings are characterised by contradictory inclinations. First, they are constantly looking for improvement of their situation. Migration is one of the many expressions of this search. On the other hand man is inclined to defend his properties. This also implies the defence of the 'own' territory against intruders, irrespective the question whether such policy is beneficial or not. ${ }^{2}$ The social relationships between different groups of people has always been of a rather conflictuous character. Strangers are only welcome if they are small in number and prepared to adjust to the dominant culture as soon as possible. If not, then they have to move to avoid permanent discrimination.

\subsection{Conservative Order}

In order to dampen permanent rivalry between different groups, two types of policies were implemented in earlier times.

A particular group was structured by means of a number of ranks. The different ranks were linked to particular functions, that were necessary to be fulfilled in order to let the group function well. In Europe the most familiar ranks were the nobility, the clerus and the so-called third rank, being a collection of skilled and unskilled workers, artisans, traders and entrepreneurs. In this way the various groups were hierarchically ranked. This also implied that competition and rivalry was limited to members of the same rank. Conflicts remain very restricted, because people of the third rank were not inclined to imitate people of the second or even the first rank. No necessity to imitate means that many desires remain unarticulated, making many things less scarce as they are now today (Achterhuis, 1988). The relationships between groups in different regions were structured by the formation of empires, states or nations. The political problems in the Middle East are a good illustration of the fact that it is a dangerous situation when a particular people does not have its own area, where they can live rather independently.

In Continental Europe the ranking society reached its culmination in the absolutist period - that is the 18th century. In contrast to the Continent was England less hierarchically organized. The kings had to consult or negotiate or even fight against a parliament, representing the higher ranks of society. This specific Anglo-Saxon democracy has always been characterised by a higher

This is in compliance with the famous Kahneman-Tverski results, that man is inclined to sacrifice chances to win a fortune for the certainty not to loose. See for their famous article (1986) in the Cook-Levi reader, 1990 . 


\section{Fout! Bladwijzer niet gedefinieerd.}

level of conflicts, but on the other hand it may be an explanation for the fact that a revolution has never taken place on the British Islands.

\subsection{The French Revolution}

The French Revolution (1789) is a very important watershed in Continental Europe. The third rank wanted to participate in the political decision making process (Grab,1989). During the 19th century the influence of the bourgeoisie and the proletariat grew, leading to important changes in the political, social and economic relationships. Whereas in the 19th century politics was mainly influenced by liberalism, during the 20th century Continental institutions transformed in social democratic direction. In concreto this meant a process of deregulation of markets, followed by increasing government intervention to protect the interests of the workers.

It is important to realize that the lines as they are sketched now, are very rough. Under the influence of a number of dramatic events conservative policies showed some temporary increase in popularity. For example during the First World War and during the period of the Great Depression of the Thirties, governments could not resist pressures to protect capital interests, leading to more restrictions in global trade. But if we take the period of the last three centuries as a whole, we can conclude to a process of gradual and partial transformation of the institutions from a mainly conservative pattern, via one which also includes liberal elements to one that includes strong social democratic features as well.

\subsection{Liberal Institutions Drive Out other Institutions}

Suppose we live in a perfectly conservative world. Then a group of people, living in a particular area, is enlightened by liberal thought. They introduce liberal institutions, expecting higher rates of growth from it. Assume this growth really happens, leading to a rise in the demand for labour. Foreign workers are attracted, in numbers that are in compliance with the needs of the liberal society. The conservative environment looses workers that had the guts to take initiative and the risks of going abroad. That is undoubtedly a loss. History of Continental Europe shows the reaction of the conservative world: political and military action to counter the liberal development. Assume this does not happen in our imagined world. The alternative is an institutional adjustment of the conservative world in liberal direction, in order not to loose too many valuable workers. In other words, liberal institutions drive out conservative institutions, under the condition of absence of political and military action.

Suppose we live in a perfectly liberal world. Then a group of people, living in a particular area, is enlightened by social democratic thought. They introduce a well organised welfare state, in which all people who are, temporarily or permanently, not able 


\section{Fout! Bladwijzer niet gedefinieerd.}

to earn an income, receive the resources, necessary for a decent living, from the state. Now productive people in the social democratic state have an incentive to emigrate to a liberal state, to lower their tax burden. The less or improductive people have an incentive to immigrate to the social democratic state. The liberal state enjoys the immigration flow of productive people, while the social democratic state gets into growing financial trouble. This means that liberal institutions drive out social democratic institutions, under the condition of absence of political and military action.

In both cases liberal institutions drive out its competitors. This result is not remarkable, because we have created a world in which political action is not allowed. So the game is played according to the rules of the market. Suppose political action is allowed in our imagined world. A liberal state does not need political action, except as an eventual re-action on political moves from other, conservative or social democratic, states. A liberal state will not be inclined to stop immigration; neither from conservative, nor from social democratic areas. A conservative state will be inclined to stop immigration from liberal states, because, if there would be any inflow, the workers are expected to be relatively unproductive. But immigration from social democratic states would be allowed, because of the expected high level of productivity of the immigrants. The social democratic state however is inclined to an overall migration stop: net tax payers are not allowed to emigrate and net benefit receivers are not allowed to immigrate. of course net tax payers are allowed to come in, but these flow will be marginal. And so with the net benefit receivers, who are allowed to emigrate.

\subsection{The Danger of Military Action}

Current practice shows that it is increasingly difficult to get the implementation of an immigration stop effective. The former soviet Union was really effective in controlling migration flows in and out. But a number of years ago (1989 especially), such an extensive system of control of all important flows of workers, capital and goods appeared to be unacceptably ineffective in terms of wealth. If we assume that a complete stop is too costly, then social democratic and conservative states must accept some adjustment in a liberal direction.

Suppose a social democratic or conservative country is not willing to accept institutional adjustments. Then they can try to convince liberal countries to adjust their institutions in conservative or social democratic direction. May be they have some success. The problem however, is that all liberal countries must be willing to cooperate in a more regulated system. Because such a kind of cooperation is not very liberal, voluntary cooperation is not probable. Then military action is the only strategy that is 
Fout! Bladwijzer niet gedefinieerd.

left. ${ }^{3}$

\section{6 Distance}

An important reason why huge immigration flows have not been taken place, is the fact that moving from one area or state to another is a costly affair. Not only the bridging of a geographical distance, but also the bridging of cultural differences including language implies considerable disutilities.

Two developments however, make that the distances has significantly reduced. First, the constant decrease in transportation costs, making it easier for people to have their job on a reasonably large distance from 'home'. Second the constant improvement in communication via television and other technologies together with the increasing numbers of people who are using English as their second language. If the distance has become under a critical minimum an explosion in migration flows may occur, under the condition that there are no other real restrictions on the immigration towards a particular country. Especially if first groups of pioneers have bridged the gap, a network of people of the same ethnicity is developed, making a strong growth in immigration more probable (King, 1994, Briggs, 1994)

\section{Public Choice Theory on Institutional Competition}

In the foregoing we have asked ourselves the question what happens if conservative, social democratic and liberal states live side by side with open borders. We have drawn the conclusion that there is a tendency towards liberal institutions. But as we all know liberalism has a difficulty in dealing with the phenomenon of public goods (Hayek, 1978) ${ }^{4}$. For our purpose we have to focus especially on so-called Local Public Goods (LPG). The concept local

3 When we look at the conflict between the Western world and a number of orthodox and fundamentalist Islamic countries and groups, we can say that, without military action, Western culture drives out Islamic culture.

4 Hayek has made a distinction between classical or AngloSaxon liberalism and Continental European liberalism. The first mentioned sort of liberalism consider as the main task of legislation to protect the individual citizen against power abuse by the government. The second sort of liberalism considers as the main task of legislation to protect the poor and powerless against power abuse by private groups such as big business and the church. Hayek himself is in this distinction a classical liberal. And these group of people tend to deny most examples of public goods to be really public goods. Hayek admits that in case of widespread poverty a welfare system is practically spoken necessary, but theoretically difficult to justify. 


\section{Fout! Bladwijzer niet gedefinieerd.}

refers to an area for which a particular good is public. What happens in a liberal world consisting of a large number of locations where liberally oriented people are living. Every community or society takes its own decisions with respect to their own set of public goods. Suppose every citizen of a particular society has to pay according to the Lindahl pricing system (Mueller, 1988). Internal equilibrium can be reached. But what if immigration and emigration is allowed and mobility costs are zero. The classic analysis of Tiebout shows us that there is an equilibrium solution, although it is not clear how in practice such an equilibrium can be reached (Tiebout, 1956). Tiebout assumes in fact monopolistic competitive markets. All citizens of every municipality possess all the information relevant for their choice of municipality.

We can distinguish two tendencies in this case. First, citizens are inclined to form clusters with rather homogeneous preferences. We see for example a split between those who prefer a more urban live versus those who prefer a more rural life. Second, another basis for clustering is the level of wealth. Those who are relatively wealthy, are inclined to vote for particular sets of local public goods, such as room for golf courses and broad ways and many parking houses for all their cars; in short many public utilities of a rather expensive kind. Those who have a relatively low level of wealth may prefer a well organised public transport system and a number of public swimming pools, because they can't afford a privately owned car and swimming pool. With respect to the financing of the public services people with lower wealth levels strive for redistributive pay systems and are inclined to look for municipalities that combine identical preferences and an average level of wealth that is higher than the own wealth level. We can imagine that people need much time to look for their optimal location. Especially in a world without mobility costs and absence of cultural differences, except the heterogeneity of preferences, it takes a lot of energy and time before a citizen has found his optimal place (Kolen, 1996). If the tax system of a particular municipality is characterized by a flat rate, then the incentive for people with a relative low income to live in a group with higher incomes on average will be weaker. If all local public goods with a club character set their prices independently from the income level of the member, then only small differences between incomes of the citizens will be optimal.

As already said, in the Tiebout world equilibrium is possible. But what will happen if the municipalities have the opportunity to implement redistributive policies. This problem is analysed by Pauly (1973). Traditional public choice analysis considers redistribution as Pareto-inferior, because the welfare of people, who pay a positive net tax, decreases in case of such a kind of policy. Moreover will the redistributive system mean that net tax payers out migrate and net benefit receivers immigrate to a municipality with such a system. As long as there is no central 


\section{Fout! Bladwijzer niet gedefinieerd.}

authority that solves the prisoners' dilemma, the externalities leading to migration flows will make redistribution on the local level impossible. Pauly however analyses this situation on the basis of a number of assumptions that differ from the traditional analysis basically on two points.

In the first place he assumes utility interdependence. People are, to a certain extent at least, altruistic. That means that the utility level reached by poor people has a positive influence on the level of utility of non-poor people. Poverty has external effects, aesthetically, morally and with respect to crime that results from it.

In the second place introduces Pauly the concept of 'distance' in the analysis. By distance he means the geographical distance as well as the frequency of contacts between various sorts of people. The rest of his assumptions are traditional or meant to make the analysis convenient.

His conclusions are rather different from those of Tiebout. In the first place is redistribution necessary for achieving Paretooptimality. In the second place determines the distance between the different municipalities the level of decision making. In the Tiebout analysis mobility costs are assumed to be zero. That implies a maximum of decentralization. In the Pauly analysis the level depends on the distance; if the distance is assumed to be zero, the pauly model would advise us, in contrast to the Tiebout model, a maximum of centralization.

We think that the introduction of utility interdependence and distance has made the analysis more realistic. A new problem has arisen however. Pauly assumes that a redistribution policy has no influence on the work effort. This assumption is convenient for the model maker, but not realistic. So we can draw the conclusion that, although the external effects of poverty are positive, the income elasticities of work effort and of immigration have a negative effect on the optimal degree of redistribution.

\section{Spational Economics on Institutional Competition}

In a recent article Hockman et al.(1995) blame the Local Public Goods (LPG) literature of an inappropriate dealing with the space dimension.

In the non-spatial theories of fiscal federalism for every type of LPG there is one optimal level of decision making. By (implicitly) abstracting from space LPG's can be ranked according to the degree of exclusion that is possible when producing a particular LPG. If exclusion of people from consumption is perfectly impossible, then the good is a perfect public good. If exclusion is perfectly possible, then the good is a perfect club good. ${ }^{5}$ In case

In the modern classification of public goods the nonrivalness condition is transformed in a continuum expressing the degree of congestion (that implies rivalry); the non-excludability condition is transformed 


\section{Fout! Bladwijzer niet gedefinieerd.}

of a club good a user charge is the optimal pay system. In case of a public good all people who cannot be excluded from consumption should pay for it. Theoretically every user of the public good should pay according to the Lindahl pricing system.

But when we bring the dimension space explicitly into the analysis, it appears that, because every LPG has its own optimal jurisdiction, all these jurisdictions overlap each other to a high degree. But this means that the fact that someone lives in a particular area, does not imply anything with respect to his preference for or against a particular LPG. In such a situation we don't have any argument to tax persons for the use of LPG's except in the case of a club good. Wherever the borderlines between the different municipalities, it is likely that people profit from some but not all of the LPG's that are offered by the municipality.

Hockman et al. refer to a solution already suggested by Henry George (1879). Everyone who owns a piece of land within the borders of a particular jurisdiction, has to pay land 'rent' to the public authority. The level of the rent depends on the amount of money the local government needs for the finance of the LPG's they offer (minus the total amount of user charge they receive from the supply of club goods). The allocation mechanism functions as follows. If the after tax profitability of land is positive, more persons want to live within the borders of the municipality under scrutiny. The price of the land will rise, leading to a lower level of profitability. If the profitability is negative, landowners will offer their land for sale and out migrate. So there is a tendency towards an equilibrium number of residents, given a particular supply of LPG's. ${ }^{6}$ of course the local government can adjust its package so as to manipulate the volume of its population. In general it has many instruments or action parameters to its disposal in order to improve the quality of the municipality.

One important problem has not been solved yet. What to do if the relatively well-to-do people leave the city, develop their own municipalities on a short distance of a large city. So they profit from their own expensive LPG's, but also from the LPG's of the large city, without paying for that. Such development is disastrous for the city, at least from a financial point of view. That makes it difficult for the city to appropriately deal with the negative externalities of poverty and congestion. In practice we see a clustering of a number of towns and villages with a large city. This clustering of jurisdictions is a task of the central

into a continuum expressing the degree of exclusion. Perfect exclusion means a perfect club good and perfect non-exclusion means a perfect public good. See for literature: Adams, McCormick, 1985.

6 The George principle holds that in equilibrium the marginal costs for attracting another resident is equal to the marginal benefits of that action. 


\section{Fout! Bladwijzer niet gedefinieerd.}

government. ${ }^{7}$ The new cluster is called a metropolitan area, governed by a metropolitan government (Olson,1969; Hockman et al , 1995 ).

With respect to our problem we must ask ourselves the question whether or not it is possible to exclude people from outside the metropolis to rivalrously use metropolitan public goods and aggravating the problem of congestion and negative externalities. Suppose metropolis A has solved its externality problems. The rich suburbs contribute in the payment of the LPG package supplied by A. If other metropolitans have not solved their problems adequately, this may induce a flow of immigrants and capital to A. As long as the immigrants are sufficiently paying for the LPG's, A develops itself along an equilibrium path. But if the inflows consists of poor immigrants who imply net costs, A will get into trouble. Expansion of economic activities will only happen as long as they are profitable. The flows of goods, capital and people that are generated, must pay the taxes that are needed to prevent or to compensate for the growing externalities. Under the assumption of a perfectly functioning public administration, metropolis A only get into trouble, if there are cost generating flows that cannot be taxed, so as to mitigate or compensate for the costs. Such a kind of imbalance happens if the redistribution in $A$ is stronger than in other metropolitans and if the benefits of just living in the centre are relatively high. This will attract people who live from some informal or even illegal activities. Costly monitoring of the use of social services and of the monitoring of tax pay duties seems the only answer to this problem of illegality.

In the next section we will look at the situation in the European Union, as far as is relevant for our problem of institutional competition.

\section{Institutional Competition in the European Union}

\section{1 Introduction}

In the former section we have seen that a free market model suggests that a large amount of municipalities of a rather homogeneous composition will be formed, assumed that all individuals possess all relevant information and that mobility costs are zero. The homogeneity of the different municipalities is especially related to the level of wealth and the preference orderings with respect to LPG's of the residents. When we look at the economic

7 Last year we have had referenda in Amsterdam as well as in Rotterdam (both Dutch metro poles) about the formation of a new and larger jurisdiction. Nearly all politicians in both cities were in favor of the new municipality. But in both referenda a large majority of the citizens voted against the proposed change! 
Fout! Bladwijzer niet gedefinieerd.

geographical map of the EU, and compare it with the migration flows between the various EU-countries, it is immediately clear that the assumptions are irrealistic. Large differences in wealth and political preferences have not led to huge migration flows. Some examples show migration over a relative large distance, but most of the time these flows occur within a particular country; from south to North Italy being a good example. Cross country border migration takes place on a rather short distance (Italians to switzerland; Finnish to Sweden; in most cases temporarily).

The problem we want to deal with in this section is the question whether the Maastricht Treaty has created a situation that will induce considerable migration flows between the various countries. We discuss a number of differences between the EU-countries that may push people to migrate and a number of factors that may be serious barriers for people to migrate. When dealing with the effect of "Maastricht", we define the Treaty for our purpose as a decision of all EU countries to prohibit discrimination between workers of EU-countries.

6.2 Determinants of Migration

A first factor that may be of relevance is the difference in wealth or income between the different countries. In the appendix in table 1 we have presented figures expressing economic growth in the different EU-countries. Although these figures do not express the wealth of the EU-nations, income is a good proxy of it. Experts as well as public consider EU-membership as a positive factor in terms of economic growth. In that sense the differences have to be rather large when we have to expect a significant push towards migration. The table shows that there is not a significant difference in growth rates between south and North. This means that the gap between the different wealth levels do not grow. A second factor that may stimulate migration is a marked difference in unemployment between the different countries. In their search for jobs unemployed are not bound to their own country, but the whole area of the EU is now their hunting ground.

Table 1 Real GDP in Western Europe (Percentage change over previous year)

\begin{tabular}{|c|c|c|c|c|c|c|}
\hline Country & 1990 & 1991 & 1992 & 1993 & 1994 & $1995^{a}$ \\
\hline Austria & 4.6 & 3.0 & 1.8 & -0.1 & 2.8 & 3.0 \\
\hline Belgium & 3.7 & 1.9 & 1.9 & -1.7 & 2.3 & 3.0 \\
\hline Denmark & 2.0 & 1.0 & 0.8 & 1.5 & 4.6 & 3.5 \\
\hline Finland & 0.3 & -7.1 & -3.6 & -1.6 & 3.9 & 5.0 \\
\hline France & 2.2 & 3.3 & 1.2 & -1.0 & 2.5 & 3.0 \\
\hline Germanyb & 5.1 & 4.5 & 2.2 & -1.1 & 2.9 & 3.0 \\
\hline
\end{tabular}


Fout! Bladwijzer niet gedefinieerd.

\begin{tabular}{|l|r|r|r|r|r|r|}
\hline Greece & -0.2 & 3.3 & 0.8 & -0.5 & 1.0 & 1.5 \\
\hline Ireland & 7.1 & 2.6 & 5.0 & 4.0 & 6.5 & 6.5 \\
\hline Italy & 2.2 & 1.3 & 0.7 & -0.7 & 2.3 & 3.0 \\
\hline N etherlands & 3.9 & 2.1 & 1.3 & 0.4 & 2.4 & 3.0 \\
\hline Norway & 1.8 & 1.9 & 3.4 & 2.3 & 5.1 & 4.5 \\
\hline Portugal & 4.4 & 2.1 & 1.5 & -0.9 & 1.0 & 2.5 \\
\hline Spain & 3.6 & 2.2 & 0.7 & -1.1 & 2.0 & 3.0 \\
\hline Sw eden & 0.7 & -1.1 & -1.4 & -2.6 & 2.2 & 2.0 \\
\hline $\begin{array}{l}\text { United King- } \\
\text { dom }\end{array}$ & 0.5 & -2.2 & -0.5 & 2.1 & 3.8 & 3.0 \\
\hline
\end{tabular}

Source: Economic Bulletin for Europe, Secretariat of the Economic Community of Europe, Vol. 44, 45, 47, United Nations, N ew York and Geneva, respectively 1992, 1993, 1995.

Forecasts rounded to the nearest 0.5 percentage point.

West-G ermany.

In table 2 to be found in the appendix we have presented macro-unemployment figures to get a rough idea of the direction of future migration flows. A remarkable feature is that, in contrast to the sixties, not only the South, but also the North is characterized by many unemployed. This development implies a serious bottleneck for people from the South to migrate to the North. From studies on national labour markets we know however, that analyses on a desaggregated level can lead to different pictures. The example of the seasonal cutting of asparagus in The $N$ etherlands is illustrative. Dutch unemployed refuse to do the job. Polish workers travel to the Dutch asparagus fields and offer themselves to do it for a rather low wage. Some of them are really getting the job, but this is illegal. In reaction to policing activities of the government the employers started to search for w orkers in other countries. In 1996 Portuguese people were willing to do the job. So on the micro level of the different occupations and regions, we see what really happens. The existence of social legislation which differs significantly between the various EU -countries, has made the unemployment figure to an unreliable predictor with respect to future migration flows. High levels of social benefits make that many potential low wage jobs are not created. But if employers discover that in other areas of Europe or even outside Europe there is a large supply for these kind of jobs, then a strong incentive exists for flows of illegal immigration.

Table 2 Standardized unemployment rates in Europe, seasonally adjusted

\begin{tabular}{|l|r|r|r|r|r|r|}
\hline \multicolumn{1}{|c|}{ Country } & \multicolumn{1}{|c|}{1990} & \multicolumn{1}{c|}{1991} & \multicolumn{1}{c|}{1992} & \multicolumn{1}{c|}{$1993^{\mathrm{a}}$} & \multicolumn{1}{c|}{$1994^{\mathrm{b}}$} & \multicolumn{1}{c|}{$1995^{\mathrm{c}}$} \\
\hline Austria & 3.2 & 3.4 & 3.7 & 4.2 & 4.4 & 4.6
\end{tabular}


Fout! Bladwijzer niet gedefinieerd.

\begin{tabular}{|l|r|r|r|r|r|r|}
\hline Bel gium & 7.2 & 7.1 & 7.8 & 8.6 & 9.7 & 9.8 \\
\hline Denmark & 9.5 & 10.4 & 11.2 & 12.2 & 12.1 & 10.1 \\
\hline Finland & 3.4 & 7.5 & 13.0 & 17.7 & 18.0 & 17.6 \\
\hline France & 9.0 & 9.4 & 10.3 & 11.6 & 12.3 & 11.6 \\
\hline G ermanyd & 4.9 & 4.4 & 4.8 & 6.1 & 6.9 & 6.8 \\
\hline Greece & 7.0 & 7.6 & 9.2 & 9.7 & 9.6 & 9.9 \\
\hline Ireland & 13.4 & 14.9 & 16.1 & 15.6 & 14.3 & 12.8 \\
\hline Italy & 10.3 & 9.9 & 10.1 & 10.3 & 11.4 & 12.1 \\
\hline N etherlands & 7.5 & 7.0 & 6.8 & 6.2 & 7.2 & 6.7 \\
\hline Norway & 5.2 & 5.5 & 5.9 & 6.0 & 5.4 & 5.2 \\
\hline Portugal & 4.6 & 4.1 & 4.1 & 5.5 & 6.8 & 7.2 \\
\hline Spain & 15.9 & 16.0 & 18.1 & 22.4 & 23.8 & 22.5 \\
\hline Sw eden & 1.5 & 2.7 & 4.8 & 9.5 & 9.8 & 9.1 \\
\hline $\begin{array}{l}\text { U nited King- } \\
\text { dom }\end{array}$ & 6.8 & 8.7 & 9.9 & 10.4 & 9.5 & 8.8 \\
\hline
\end{tabular}

Source: Economic Bulletin for Europe, Secretariat of the Economic Community of Europe, Vol. 44, 45, 47, U nited Nations, New York and Geneva, respectively 1992 (p. 14), 1993 (p. 30 ), 1995 (p. 12).

a Adjusted for comparability, except Austria, D enmark and G reece.

b Idem

c $\quad$ Figures of the second quarter of 1995

d West-Germany

e Average unemployment rate forecast by OECD

A third factor is the presence of social legislation that offers entitlements to people who are not able to care for themselves. These rights to receive an income or particular services diminish the necessity to look for a job and a living in other countries. Benefit recipients in liberal and the lower ranked recipients in conservative countries have an incentive to migrate to countries with a more social democratic regime. $\mathrm{N}$ et tax payers in especially the social democratic countries have an incentive to migrate to countries with a lower tax level, that are the conservative and especially the liberal countries. In table 3 we have divided the EU-countries into the three categories, as they are distinguished by EspingAndersen. He has used the concept of "de-commodification" as is developed by Polanyi (1944). The social rights that are developed in the welfare state differ in the degree to which they permit people to make their standards of living independent of pure market forces. The 
Fout! Bladwijzer niet gedefinieerd.

liberal countries are the countries with the lowest scores and the social-democratic countries with the highest scores. The conservative countries take a middle position.

Table 3 The clustering of w elfare states according to conservative, liberal and socialist regime attributes

\begin{tabular}{|c|c|c|}
\hline conservatism & liberalism & socialism \\
\hline strong & strong & strong \\
\hline $\begin{array}{l}\text { A ustria } \\
\text { Belgium } \\
\text { France } \\
\text { Germany } \\
\text { Italy }\end{array}$ & $\begin{array}{l}\text { Australia } \\
\text { Canada } \\
\text { Japan } \\
\text { Switzerland } \\
\text { United States }\end{array}$ & $\begin{array}{l}\text { Denmark } \\
\text { Finland } \\
\text { N etherlands } \\
\text { Norway } \\
\text { Sw eden }\end{array}$ \\
\hline medium & medium & medium \\
\hline $\begin{array}{l}\text { Finland } \\
\text { Ireland } \\
\text { Japan } \\
\text { Netherlands } \\
\text { Norway }\end{array}$ & $\begin{array}{l}\text { Denmark } \\
\text { France } \\
\text { G ermany } \\
\text { Italy } \\
\text { N etherlands } \\
\text { U nited Kingdom }\end{array}$ & $\begin{array}{l}\text { Australia } \\
\text { Belgium } \\
\text { Canada } \\
\text { Germany } \\
\text { New Zealand } \\
\text { Switzerland } \\
\text { United Kingdom }\end{array}$ \\
\hline low & low & low \\
\hline $\begin{array}{l}\text { A ustralia } \\
\text { Canada } \\
\text { Denmark } \\
\text { New Zealand } \\
\text { Sw eden } \\
\text { Switzerland } \\
\text { United Kingdom } \\
\text { United States }\end{array}$ & $\begin{array}{l}\text { Austria } \\
\text { Belgium } \\
\text { Finland } \\
\text { Ireland } \\
\text { New Zealand } \\
\text { Norway } \\
\text { Sw eden }\end{array}$ & $\begin{array}{l}\text { Austria } \\
\text { France } \\
\text { Ireland } \\
\text { Italy } \\
\text { Japan } \\
\text { United States }\end{array}$ \\
\hline
\end{tabular}

Source: G.Esping-Andersen (1990),p.74. 
A fourth factor are the transportation costs to bridge the geographical distance that have constantly diminished as a result of progress in transport technology..

A fifth factor is related to the existing cultural distance between the different EUcountries. Although the different cultures emerge to a certain extent, differences that exist for already more than two thousand years will not disappear in one or two decennia. Hofstede has developed a culture theory and have tried to measure culture by means of four dimensions (H ofstede, 1980). In the first place do we have the difference between masculine and feminine societies. In masculine societies typical masculine values, such as threatening and showing your strength, are dominant, whereas in typical feminine societies feminine values, such as protecting and caring, dominate.

In the second place Hofstede distinguishes between societies with a small versus societies with a large pow er distance. The concept of pow er distance expresses the distances as perceived by a person between the ow $\mathrm{n}$ rank and the higher rank(s). It measures the degree of hierarchical thinking in a particular society.

A third dimension is individualism, as opposed to collectivism. In some cultures people are used to think in terms of "we" or "they", whereas in other cultures large numbers of people have developed a way of thinking in which the "I" and "him" or "her" take a central place.

A last and may be the most elementary dimension of culture is the degree of uncertainty avoidance. Some people are inclined to do everything to reduce the uncertainty of life, whereas other people have learned themselves to live with a rather high level of uncertainty. In table 4 we have presented the scores of the EU-countries with respect to the four dimensions just discussed. The larger the difference in scores, the more difficult it is for an individual to migrate. We see that the Northern countries are highly individualistic, in contrast to some of the Southern countries as Portugal and G reece. With respect to power distance we see that countries as Belgium, France, Portugal, Spain, Italy and Greece are more hierarchical in their thinking than the other countries. With respect to masculinity we see that the Scandinavian countries and The Netherlands are very feminine, in contrast to Central and South Europe. Uncertainty avoidance shows more or less the same picture as is the case with masculinity. An overall conclusion must be that there are significant differences in culture, which may function as a serious bottleneck for migration. In interpreting the scores we must know that Hofstede has constructed them in such a way that they can run from about zero to about hundred. ${ }^{8}$

\footnotetext{
If one is interested in the technical aspects of the calculation of the scores, made by Hofstede, then one must look for a careful description chapter 2 of his "Culture's Consequences".
} 
Fout! Bladwijzer niet gedefinieerd.

Table 4 Hofstede-scores for 15 European countries

\begin{tabular}{|c|c|c|c|c|}
\hline \multirow{2}{*}{ Country } & \multicolumn{4}{|c|}{ Cultural Dimension } \\
\hline & DV & PDI & MAS & UAI \\
\hline A ustria & 55 & 11 & 79 & 70 \\
\hline Belgium & 75 & 65 & 54 & 94 \\
\hline Denmark & 74 & 18 & 16 & 23 \\
\hline Finland & 63 & 33 & 26 & 59 \\
\hline France & 71 & 68 & 43 & 86 \\
\hline G ermany & 67 & 35 & 66 & 65 \\
\hline Greece & 35 & 60 & 57 & 112 \\
\hline Ireland & 70 & 28 & 68 & 35 \\
\hline Italy & 76 & 50 & 70 & 75 \\
\hline N etherlands & 80 & 38 & 14 & 53 \\
\hline Norway & 69 & 31 & 8 & 50 \\
\hline Portugal & 27 & 63 & 31 & 104 \\
\hline Spain & 51 & 57 & 42 & 86 \\
\hline Sw eden & 71 & 31 & 5 & 29 \\
\hline Un. Kingdom & 89 & 35 & 66 & 35 \\
\hline
\end{tabular}

Source: Cultures and O rganizations; Software of the Mind, IRIC, U niversity of Limburg, M aastricht 1991.

IDV = Individualism index

PDI = Power distance index

MAS $=$ Masculinity index

UAI = Uncertainty avoidance index

Although there are severe cultural barriers in the EU, a number of developments has had a positive effect on the mobility of people within the $\mathrm{EU}$. In the first place is the language barrier lower than in earlier times because the increase in the number of people that speak some English. $\mathbf{O}$ ne of the main reasons for the growing impact of English is the enormous 
growth in use of communication media, of which television has the greatest impact. Via television there is a kind of global culture growing. This diminishes the cultural gap betw een the various countries in the world. In our case of the EU we can expect especially a smaller gap between North and South Europe.

A factor that makes it easier for people to bridge a cultural gap is the presence of groups of 'pioneers' who are already migrated to another countries. The first immigrants of a particular ethnicity must really deal with cultural differences. If they succeed and stay, they form, most of the time, a group who have frequent contact with each other and with their home country. They form a network with contacts in their home country. ${ }^{9}$ If the pioneers are successful, other people will also make plans to migrate. In this way a small flow can explosively grow, at least as long as there are opportunities for them to earn a decent living.

Another factor that may be of high relevance for understanding and predicting the direction of future migration flows, is the demographic development (King, 1994; Briggs,1994). Many immigrants appear to be fathers of families with a relatively high number of children. For these families is having an income a matter of survival. This makes it easier for one of the parents to decide to go abroad. If the father is successful he stays and sends regular remittances to his family. During the sixties and seventies this has happened in Europe. In many cases the father changed his original plan to stay only temporary into a request to the host country to allow also his family to come and to establish in the host country permanently. Most governments have conceded to let the families reunite.

A last factor that may be relevant are the differences in climate. People who are looking for opportunities to live and work in richer areas undoubtedly prefer a Mediterranean to a more moderate sea or continental climate. An irregular life in Southern Italy is much easier than in Northern Sweden. In table 5 have we presented the average temperatures in the periods January and June of the EU-countries plus Norway. It is clear that this factor is a barrier to a flow of irregular labour from South to North.

\subsection{Expected Migration}

Up to know we have discussed the factors separately, that is under the ceteris paribus condition. When we put the factors together, we can make a few additional remarks.

In the first place we see that there is a dominating difference between South and North, although not only the South, but also the North has its periphery (Ireland, Scotland, North Scandinavia). In terms of wealth and income the South is relatively poor, whereas the North is relatively rich. In terms of demography the Southern rate of population growth is higher than the Northern rate. Looking at the level of social assistance and social security we see that the Southern levels are low er than the Northern levels. This fact is not an expression of different political preferences, but a matter of

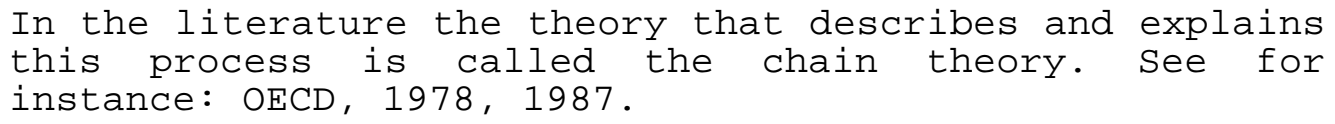


difference in wealth. Taking the factors just mentioned together, they all indicate a future flow of migration from South to North. When we consider the emergence of income growth rates and assume that the positive prospects influences significantly the perspectives of the workers, then we can draw the conclusion that a relatively small migration flow is more probable than a more voluminous one. When looking at the unemployment figures, we must expect an even lower level of migration. The N orthern countries, although on average very rich, are in trouble. Many people are unemployed and the welfare system, supported by a majority of the voting people, is under heavy (financial) pressure. This will undoubtedly diminish the chances for immigrants to get an attractive job.

A second remark is that we must distinguish between several kinds of migration. There is a group of people who consider themselves as chanceless in the home country and are looking for better opportunities. They take initiative, go abroad and accept a very low level of wealth. They accept it, because they perceive a better perspective, compared to the situation in their home country. Illegal jobs, social benefits, or barter exchange are familiar ways for them during their waiting time; waiting for their chance to get a legal, well paid job that can lead to a decent living. In the migration literature this is called "push"-flows. Another group of immigrants are people who are hired by foreign employers. They recruit new workers in foreign countries, because the foreigners are expected to be better than the autochthon people. Better in the sense of 'not indulged', hard working and eager to learn something, while satisfied with a rather low wage. In the migration literature this is called "pull"-flows. What we can expect in the context of a free European labour market is that the push-flow will be rather small and going from South to North, but that the second group may increase. Especially if there are no cultural barriers, a free European labour market will to an increasing extent offer the opportunities to match efficiently the vacancy - unemployed of the same characteristics. Expressed in technical terms does it mean a shift of the V-U-curve to the left (Hansen, 1993). In this case we cannot discover a particular pattern in the migration flows. They can stream from every country to every other country. The immigrants can be very temporary to permanent. When we look at the economic restructuring of the global economy, then we can especially expect temporary detachment of (highly) skilled workers (King, 1994).

A third remark is about the distance factor. Decreasing transportation costs have made migration cheaper, in whatever direction. The emergence of a kind of global culture and of a global information network will make it easier to move. In this respect we want to memorize results from empirical research of Mintzberg (1990) about the openness of organisations of a Roman Catholic culture relative to that of Protestant like organisations. It appeared that people from Roman Catholic descent had little difficulties in working in an organisation that was managed in a Protestant way. People coming from Protestant run organizations had much difficulty in working in an organization run by Roman Catholic modes of behaviour. The explanation of the difference he found was that a Protestant culture is far more explicit. Rules and agreements must be taken literally. If one disagrees with other people, one is expected to make that explicit. If one does not oppose clearly, one is supposed to favour particular arrangements. If one says yes, it is yes, and not no or tomorrow. In this respect is living in a Roman Catholic culture more complex 
and only easy for the real insiders. During the years they have learned to interpret words, tones of discussion or particular events. If a Protestant worker has to work in a Roman Catholic environment, he constantly makes mistakes because of misunderstandings. If a Roman Catholic worker has to work in a Protestant environment however, it is rather clear for him what is really expected. Although he may dislike Protestant cultural characteristics, one barrier has fortunately removed. Applying this result to our migration problem, a flow from South to North would be stimulated in contrast to a flow from North to South.

What is left, is Hofstede's view that cultural roots are very tenacious. Two thousand or more years of experience of various rules and habits cannot be changed in one or two decennia. The reluctance of Scandinavia to enter the EU, the French nationalism and the $B$ ritish resistance to processes of European centralisation are examples, illustrating the fact that Europe is far from culturally homogeneous.

Concluding this section we have the impression that the push-flows from poor to rich will be of limited size. The pull-flows will be larger, but if the administrations of the different social systems are interconnected, this will not grow out to a serious problem. When we look at the ethnic minority groups in the EU-area, we must conclude that the external migration is far more serious than the internal migration. That will be the subject of section 8.

In the next section we will deal with the question whether Brussels has a role to play in the eventual coordination of social arrangements, that are concluded in the different nations of the $E U$.

\section{Towards a European W elfare State}

\subsection{Different Views on the European Future}

If Brussels does not develop special policies to effectively deal with the problems that are induced by these growing flows, we can predict severe and growing social tensions and economic mismatches. The "push"-flows will lead to a kind of social shopping. The "pull"flows will lead to a growing claim on the generous social funds of the rich and social democratic countries. If foreign workers become unemployed they are inclined to use funds in that country that is generous to its unemployed. If not, then they will be inclined to return to their home country. The third mentioned flow, coming from outside the EU, has been limited up to now because of the immigration stop that is announced during the seventies. Abolishment of this measure could be disastrous for most or may be all EU countries. So the question is now : what must Brussels do?

From a liberal point of view all members will be advised to introduce liberal policies. Brussels must do nothing. Every foreigner falls back on the social assistance system of his home country, except if a host country accepts a foreigner as being a permanent citizen of his new country. If the economic developments of the different members converges, the time will come that the social assistance benefits will be more or less the same. If a number of European countries decide, by a vast majority, that they want 
to be part of a bigger whole (EU), they assign authority to the EU-government. From then on Brussels can take its decisions with respect to a EU-minimum of social assistance. This is considered the only real and liberal road to individual freedom in Europe.

From a conservative point of view all members will be advised to implement a conservative, that is a corporatist structure to establish consensus. Brussels must also develop a consensus producing tripartite consultation platform. There can every rank, industry, vocation or guild establish its own European consultation platform. These European corporative associations can coordinate the different national policies. If the social security arrangements differ much from country to country, then coordination must take place, deciding about the allocation of the EU workers over the different social jurisdictions. In case of a strong convergence of income levels, the various countries may decide upon the formation of a real EU-authority, which could take its decisions after consultation of the various European corporative associations. This is considered the only real and conservative road to European brotherhood.

From a social democratic point of view all members will be advised to implement social democratic institutions. Brussels has the task to stabilize European expenditures on a level that is necessary to create and maintain full employment. The European unions must negotiate with the European employers about wage level and additional employment for discriminated groups. The EU-government has the task to intervene into the negotiations if the general European interests are not served well by the negotiating parties. And last but not least has the EU-government the task to redistribute resources from the rich to the poor parts of the EU. European solidarity means that in terms of income as well as in terms of social services a European minimum has to be established and differences diminished. After the establishment of such European institutions, free flows of labour can take place. The disadvantages of the free labour market are made as small as possible. $\mathrm{O}$ the other hand are the activities that are advantageous for all parties given free way. This is considered the only real and social democratic road to an equal and harmonious European society.

\subsection{Assessment of the Different Views}

Assessing the various roads in the context of the current situation in Europe, we must say that the liberal view fits the modern process of secularisation and individualisation best. It has the advantage that it accounts the individual for the consequences of his behaviour, giving him a strong incentive to use all his capacities. This implies that individuals are maximally motivated to change activities if changes in circumstances require this. European experience shows how ever that in a system of free markets the inequality can be severe. This has led to the formation of pressure groups focussed on a change in the social structure. Liberalism has never formulated a clear answer to this problem of social conflict.

In the course of time many Europeans have accepted the social democratic ideas about human rights, including the right of every person to get a number of social services, housing, education and health. In this respect social democratic thinking has had a strong influence on European public opinion. It has dampened social conflict by institutionalization of a number of their ideas, such as progressive taxation. $\mathrm{On}$ the other hand, social democrats did not understand that solidarity has its price. People are not 
willing to be solidary with an enormous number of poor people, irrespective the costs. The mass of the people have appeared not to be prepared to bear a tax burden of $60 \%$ or higher, in the name of an abstract principle or in the name of an infinite flow of people all over the world. Local solidarity in a global society may in principle be unacceptable, but seems a practical necessity.

The advantage of the conservative road to order is that it offers a functional perspective. It has given people a meaningful context, which has limited competition and rivalry between people to a certain extent. $\mathrm{O}$ n the other hand can we draw the conclusion that the conservative institutional framework was not only stabilizing social relationships, but it made economic relationships very rigid. It has appeared to be a structure that is very suited for vested interests to defend itself against new interests. Technical, economic and social progress is easily hampered in a conservatively organized society. Extremely formulated will the conservative strategy lead to the order and stability of a cemetery.

Up to now we have dealt with liberalism, social democracy and conservatism as ideal types. When we want to deal with them in a more historical way, we must admit that all three currents has adapted themselves to changing circumstances. Nevertheless is it useful to define a never changing hard core of the three currents. The liberal hard core concerns the individual freedom, not only as an ultimate goal, but also as an efficient instrument towards wealth for everyone. The social democratic hard core concerns the equality of all men, which implies that every individual has the right to satisfy a number of basic needs. The conservative hard core concerns the inequality of men, leading to a natural hierarchy. This hierarchy leads to order if every rank is aware of its rights as well its duties or (moral) obligations.

The liberals have difficulties in dealing with social conflicts. The social democrats have problems with the experience that a process of equalization has its price and even its limits. The conservatives have difficulties with the requirements of fast changing technical and economic structures. Technical and economic flexibility is hampered by the conservative need for a careful reformulation of the rights and obligations of the newly emerging ranks.

An efficient solution to the problem of European institutional competition cannot be based on one ideology. The EU must find a solution that maximizes the advantages of all three views and minimizes the disadvantages of them. Without pretending to have found the solution, we just want to give an example of a workable proposal, meant as an illustration of our multi-ideology argument.

\section{PROPOSAL MEANT AS AN ILLUSTRATIVE EXAMPLE}

(1) For the moment not any country must be enforced to change its social system significantly; only voluntary adjustments directed to harmonisation must be welcomed.

(2) Every adult citizen who is unable to satisfy his basic needs, has the right to receive 
a social assistance benefit and to be eligible to a number of elementary services, such as housing, education and health care. His home country has the obligation to pay.

(3) If a worker migrates from one EU-country to another EU-country, then he falls under the social jurisdiction of the host country. He pays the obligatory social premiums and can use the rights he has received.

(4) If a foreign worker gets unemployed, he will receive an unemployment benefit for a couple of months, from the host country. D uring that period he can search for another job, in the host country as well as his home country. After some time the benefit decreases, until the maximum time of the unemployment security has achieved. Then the unemployed falls back on the social assistance of the home country. The same holds if a foreign worker gets disabled and cannot work anymore. He will receive a disability benefit during some time. During that period the level of the benefit decreases, until the maximum period of the disability security has reached. Then he falls back on the social assistance of his home country.

(5) If a worker has worked in several EU-countries, and he becomes unemployed or disabled, then during the first months the host country is paying the benefit. After some time the benefit will be paid by all countries where the worker has worked and paid social premiums. The different contributions are determined by the level of the premiums and the length of the period that premiums has been paid.

(6) The task of "Brussels" is to set up a social administration that functions as a clearing house. This social office gets all the information with respect to the workers, their premiums paid and the benefits they have received. The office calculates the benefits and premiums to be received and paid on the basis of the different national legislations. So the task of our European Social Clearing H ouse is limited to the activities 'registration', 'calculation' and 'clearing'. If 'Brussels' would operate along the lines just sketched, would that mean an enormous increase in the efficiency with respect to labour market transactions throughout the EUarea.

Meanwhile the EU can go on by trying to harmonise the different social systems. The convergence of wealth levels will appear to be a crucial factor. A process that lowers cultural barriers would enhance an efficient labour market match. When we look at the ethnic conflicts in the EU-countries at the moment, then it is immediately clear that the intra-EU migration is not a serious problem at the moment. If Brussels will be able to develop efficient labour market policies, then the EU can prevent serious social conflicts. But the observation of ethnic conflicts gives rise to another question, that has to do with the immigration from outside the EU. Notwithstanding the official immigration stop is the number of non EU-citizens in the EU-area high and increasing. Especially there is a rise in political asylum seekers and in illegal immigration. In the next section we will make a number of remarks about this increasing problem.

8. European Solidarity and G lobal Competition 
Within the EU-borders some migration has taken place in the postwar period. Especially people from the South went to the North. But when we consider the main ethnic minority populations in the EU-area, then we discover immediately that the external migration is far more voluminous. In appendix A we have presented some quantitative information about the main development in this respect. M ost of these immigrants are located in the large metro poles of the EU. Surinams, Maroccans and Turkish people in the City Holland, Turkish in Berlin, West Indian people and people from India and Pakistan in London, Algerians and Maroccans in Paris, Lyon and especially Marseille are good illustrations of this phenomenon.

Can we apply the analyses we used in section 3, to clarify these flows? The analysis of Tiebout can be applied to understand the flow of poor people to the large cities. Many people live in situations without any perspective. Many of them think it worthwhile to live in the slums of large cities in their ow $n$ country. But others take the initiative to (illegally) immigrate to richer countries. Then they find a place in the slums of the large cities there. If these migrants have already connections with relatives who have appeared to be successful, then their chances are better. But the other are just waiting .....(M CDonald, Solow, 1985)..$^{10}$ The Tiebout analysis explains the flow of rich people from the large cities, to get their ow $n$, more homogeneous municipalities. Hochman et al. explains why the rich settle themselves in the neighbourhoods of large cities, more than in small villages in the country. They only want to take distance from the poor and the problems of violence and other forms of criminality. To take distance of 10-30 miles, the attractive LPG 's of the city and the life style products of high quality remains within their scope. The Pauly analysis can explain why large cities still exist apparently accept that poverty belongs to a large city and that a kind of w el fare system is needed to keep the problem under control.

The libertarian problem of having "not any welfare program at all", does not exist in Europe. But on the other hand, moral hazard at the social benefit and subsidy side and evasion at the tax and social premium side shows undoubtedly that there are limits to the grow th of the welfare production.

If constructors of w elfare systems ignore the fact that most people are only solidary with some other people, to some extent, these systems will sooner or later go bankrupt.

As is the case with the organisation of a w elfare state, the immigration policy reflects to a

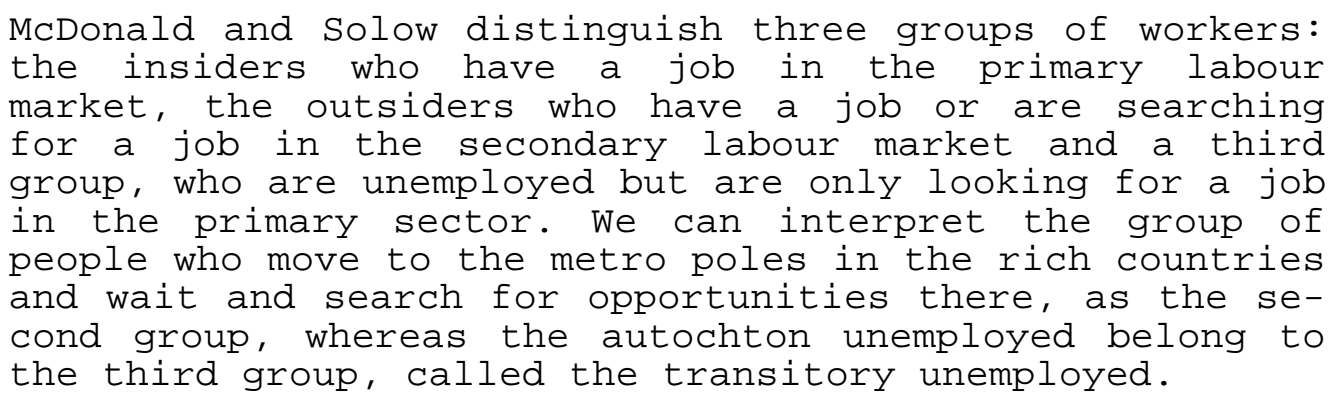


certain degree the political view of the dominant groups in society.

The conservative view on immigration implies a restrictive admittance policy and extensive monitoring activities to prevent illegal immigration. Selective immigration of a pull character may be allowed: employers recruit foreigners because their skills are scarce. They are lodged together and stay only temporary. If necessary, a system of rotation is implemented, to prevent that the foreigners get integrated into the host society. G ermany of the sixties and seventies followed that road. The Arab oil countries do it this way, but much more extreme than the $\mathrm{G}$ ermans did.

The liberal view would be, at least if the world is one immense market economy, to abstain from any protection. The market must decide who is working and living in certain areas; not governments. A liberal island in a world of regulated and therefore highly disequilibrated sea how ever, would be flooded in the absence of dikes ${ }^{11}$.

The social democratic view would allow free migration if there would be a global system of welfare and full employment maintenance. But a social democratic island in a badly regulated sea, would be flooded by poorly equipped people. So, an immigration stop is unavoidable for such a social democratic island. Whereas for liberals such a stop is necessary to protect the individual freedom of the insiders, for socialists how ever, the stop means a break in the international solidarity. It makes social democrats feel guilty about it, leading to a softening of the necessary monitoring of the (illegal) flows.

Conservative toughness, liberal tolerance and social democratic ambiguity are the ideal typical answers to the problem of immigration from poor people to the rich centres in the world. In European political practice Conservative and social-democratic thought are stronger than liberal thought as we look at the official statements of political parties. But the idea of individual freedom has strongly influenced most people.

The necessity of coalition formation implies the possibility of inconsistent compromises. The question is now, whether we can construct more efficient combinations of policy measures. It must be possible to combine conservative seriousness in keeping the law, the liberal freedom of individuals to get an efficient market economy and a social democratic solidarity transfer system, of which the extendedness and generosity is dependent on the payability of the system. Without pretending to have found the solution, we just want to give an illustration.

* the maximum degree of redistribution is determined by the wealth level and the optimal tax rate (a Rawls-like principle) and the income elasticity of social conflict

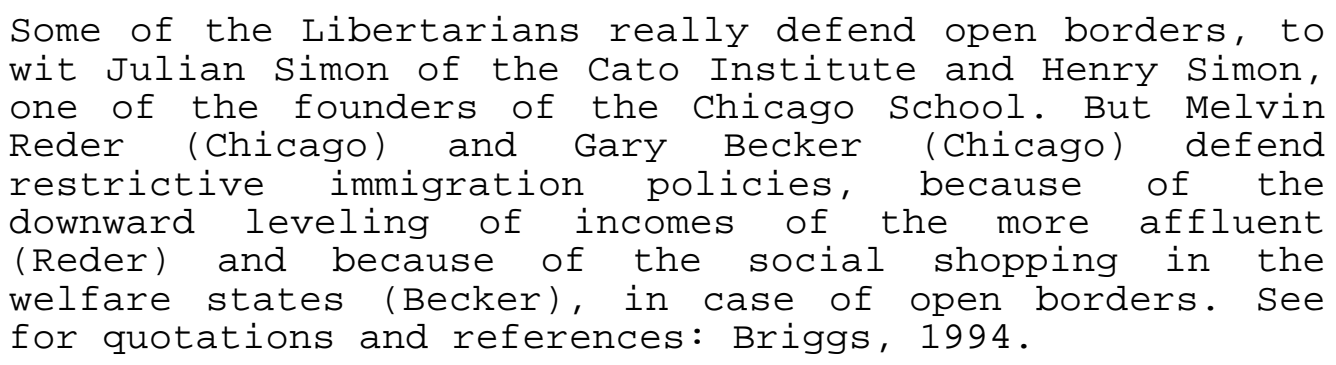



* legislation is necessary to maintain a free market economy including a maximum solidarity transfer;
* the solidarity transfer must be divided into three parts: administrative and policing costs (1), transfers to poor outsiders of a particular jurisdiction (2) and transfers to poor insiders of the jurisdiction under scrutiny (3);
* if a jurisdiction has delivered a maximum effort to be solidary, the state has the moral right to use its policing equipment as effective as possible. First to keep outsiders out of a particular area; second to keep outsiders out of a particular social fund; third to let every citizen fulfil his duty to pay taxes according to the rules of the taxing system.

In this solution effective are law and order, a free market economy and internal and external solidarity transfer efficiently combined.

Applying to our problem of the European welfare state in the context of global competition, we would advise the EU to contribute as much as it can to reduce sources of social conflict, inside as well as outside. The maximum tax receipts must be divided between European administrative and policing costs, solidarity transfers inside the EU and solidarity transfers to poor outside the EU. This will give the EU the legitimacy to maintain its immigration stop, which must be made effective by spending a relatively high amount of resources to monitoring. Because an effective stop is, how ever legitimized for EU-citizens, morally hard to accept, can the EU-state add two policies: it can press for a different global structure (1) and it can offer its citizens administrative help in organising effective solidarity on a private basis. Up to now, private solidarity is called charity and has a connotation of "only for soft people and of "nonbinding" and "voluntary". A different atmosphere is necessary to make the product "private solidarity" to a booming industry.

With respect to the first point we can mention two measures, meant as an illustration, that can be striven for. The first is the development by the $\mathrm{UN}$ of a plan for a global pension arrangement. We may expect that the implementation has the potential to diminish demographic pressures. ${ }^{12}$

A second example may be the establishment of a number of asylums, spread over the world. These asylums must be designed to host large numbers of people, who cannot earn their own living and/or are politically threatened. A minimum of care must be offered: nutrition, shelter, education, discipline, work, sport. A constant selection must take place to determine which people can be sent back home. These asylums will also make it easier to

It is an established fact that many parents in the poorer countries regard their children as a safety net for the period when they become too old to earn their own living. A globally guaranteed pension might have a significant effect on the number of children per family. 


\section{Fout! Bladwijzer niet gedefinieerd.}

implement tough immigration stops. A rich country will never send people away, but always send people to somewhere; and that is morally spoken a marked differencel Global solidarity must be interpreted as "helping people in their ow environment. Immigration ought to have a pull character, not only a different place to wait for...

\section{Epilogue}

This article was on institutional competition. Three institutional figurations has been discussed: the conservative, the liberal and the social democratic one. We have seen that all three stresses a particular aspect, paying less attention to the other aspects. The conservatives focus their attention on the problem of maintaining hierarchical order and law. The liberals however, take the individual freedom and efficiency and the social democrats the equality and social justice as their hard core. But every institutional framew ork must give an answer to all the three questions of efficiency, justice and control; we must realise that the three problems are highly interrelated. In the liberal approach perfect control and justice is assumed as an automatic and spontaneous consequence of individual freedom. In the social democratic approach the amount of individual freedom that is possible, is derived from the way how justice can be achieved. Control is an implicit and automatic consequence of the achievement of justice. In the conservative approach it is assumed that efficiency and justice are automatically achieved if the problem of control is solved: everyone in his rank and on his place, supported by a well organised hierarchical structure, including monitoring and sanctioning if necessary. M ore apparent how ever, will be that actual frameworks are mixes of elements of the three approaches. The danger of mixes are the potential inconsistencies (Keizer, 1996b). So we can finish by concluding that more consistent institutional mixes drive out less consistent mixes. 
Fout! Bladwijzer niet gedefinieerd.

\section{$\underline{\text { References }}$}

(1) R.D.Adams, K.McCormick, Private Goods, Club Goods and Public Goods as a Continuum, Review of Social Economy, vol.34, no.3, 1987.

(2) H.Achterhuis, Het Rijk der Schaarste (The Institutional Character of Scarcity), Baarn, 1988.

(3) I.Berlin, Four Essays of Liberty, 0 xford, 1984.

(4) E.Bernstein, De voorwaarden tot het socialisme en de taak der sociaal-democratie, Amsterdam, 19810 riginally published in 1899).

(5) W.Blumel, R.Pethig, O.von dem Hagen, The Theory of Public Goods: A Survey of Recent Issues, Journal of Institutional and Theoretical Economics, 142 (1986).

(6) V.M .B riggs,J r., International M igration and the Receiving Countries, Proceedings of the 15th Conference of the Belgian-Dutch Association for Post-Keynesian Economics, Antw erp, B el gi um, october, 1994.

(7) J.M.Buchanan, G.Tullock, The Calculus of Consent, Ann Arbor, University of Michigan Press, 1962.

(8) K.S.C ook, M .Levi, The Limits to Rationality, The U niversity of Chicago Press, 1990.

(9) G.Esping-Andersen, The Three Worlds of Welfare Capitalism, Polity Press, 1990.

(10) F.Fukuyama, The End of History and the Last Man, Penguin Books, 1992.

(11) F.Fukuyama, Trust, Hamish Hamilton, 1995.

(12) H.G eorge, Progress and Poverty, San Francisco, 1879.

(13) W.G rab, De Franse R evolutie (The French R evolution), Atrium, 1989.

(14) B.Hansen, Fortress Europe, in: B.Eichengreen, L.UImann (eds.), Labor in an Integrated Europe, M cMillan, 1994.

(15) F.von Hayek, Liberalism, ch.9 of New Ideas in Philosophy, Politics, Economics and the History of Ideas, London and Henley,1978.

(16) O.Hochman et al., On the Optimal Structure of Local Governments, American Economic Review, vol.85, no.5.,1995.

(17) G .H ofstede, Culture's Consequences, Sage Publications, 1980.

(18) Th.H obbes, Leviathan, Harmondsw orth, Middlesex, England, Penguin Books, 1968 (O riginally published in 1651).

(19) D.Hume, Treatise of Human Nature, Oxford University Press, 1941 (originally published in 1739).

(20) R.King, Migration in a Historical Perspective, Procee

dings of the 15th conference of the Association of Post-Keynesian studies, Antw erp, november, 1994.

(21) P.K.Keizer, An Essay on the Logic of Solidarity, Meteor, WP 96-007, University of Maastricht.

(22) P.K.Keizer, A Critical Assessment of Recent Trends in Dutch Industrial Relations, Meteor, RM 96-025, U niversity of M aastricht.

(23) A.Kolen, Een naald in een hooiberg, Inaugural, U niversity of Maastricht, 1995.

(24) J.Locke, The Second Treatise of Government, Indianapolis, Bobbs, Merril, 1952 (originally published in 1690). 
(25) I.M .M cD onald, R.M.Solow, W ages and Employment in a Segmented Labor M arket, The Q uarterly Journal of Economics, N ovember, 1985.

(26) H.M intzberg, Culture and O rganization, Lecture in Amsterdam, november, 1990.

(27) W.Molle, Van Mourik, International Movements of Labour under Conditions of Economic Integration: The Case of Western Europe, Journal of Common Market Studies, volume XXVI, 03 M arch, 1988.

(28) D.M ueller, Public Choice II, Cambridge University Press, 1989.

(29) OECD, The M igratory Chain, Paris, 1978.

(30) OECD, The Future of Migration, Paris, 1987.

(31) M.OIson Jr, The Principal of "Fiscal Equivalence": The Division of Responsibilities among different levels of Government, American Economic Review, May, 1969, 59(2), pp.479-87.

(32) R.Pauly, Income redistribution as a Local Public Good, Journal of Public Economics, (1973), pp.35-58.

(33) A.Smith, The Theory of Moral Sentiments, edited by D.D.Raphael, A.L.Macfie, Liberty Fund, Indianapolis, 1982 (originally published in 1759).

(34) A.Smith, An Inquiry into the Causes of the Wealth of Nations, London, 1776.

(35) G.J.Stigler, Tenable Range of Functions of Local Government. In: Joint Economic Committee, Subcommittee on Fiscal Policy, Federal Expenditure for Economic Growth and Stability, Washington, 1957; pp.213-219.

(36) A.de Sw aan, Coalition theory and Cabinet formation, A msterdam, 1973.

(37) C.Tiebout, A Pure Theory of Local Public Goods, Journal of Political economy, 0 ctober, 1956, 64(5), pp.416-24.

(38) J.Tinbergen, Income distribution and Redistribution Policies, Amsterdam, 1975.

Piet K.Keizer.

Berkeley.

11-06-96.

fax: 31-(0)43-3261555. (M aastricht, The N etherlands).

e-mail: p.keizer@algec.rulimburg.nl (The Netherlands). 